\title{
Biodegradation Study of a Novel Poly-Caprolactone-Coffee Husk Composite Film
}

\author{
Daiana Cristina Borghesi ${ }^{a}$, Maíra Fernanda Molina ${ }^{a}$, Marcos Antônio Guerra ${ }^{a, b}$, Maria Gabriela
}

\author{
Nogueira Campos ${ }^{a, *}$ \\ ${ }^{a}$ Institute of Science and Technology, Federal University of Alfenas - UNIFAL-MG, Brazil \\ ${ }^{b}$ Department of Technology and Development, M\&G Fibras Brasil S/A, Brazil
}

Received: October 1, 2015; Revised: March 5, 2016; Accepted: April 17, 2016

\begin{abstract}
Plastic disposal is a worldwide issue due to its long degradation time. Environmentally degradable polymers (EDPs) have received considerable attention because of their faster degradation. However, the use of EDPs is limited by high cost and restricted properties. The incorporation of organic fillers is an alternative to reduce cost while increasing biodegradation. Poly-caprolactone (PCL) is a biodegradable polyester compatible with organic fillers. Coffee husk $(\mathrm{CH})$ is a sub-product of coffee processing with potential use as organic filler. We prepared a novel PCL-CH composite film and investigated the effects of $\mathrm{CH}$ incorporation on the biodegradation of PCL. Biodegradation study was carried out in soil for 120 days, and evaluated by weight loss measurements. Additionally, soil microbiological and granulometric analyses were performed. Bacteria and fungi were found in the soil that was classified as sandy. The composite film degraded twice faster than PCL film probably due to the adhesion of microorganisms on the coffee husk.
\end{abstract}

Keywords: Poly-caprolactone, Coffee Husk, Composite, Biodegradation, Soil

\section{Introduction}

Currently, plastics market is in constant expansion due to the wide field of application of these materials. According to the ABIPLAST (Brazilian Association of Plastic Industry), in 2013, 299 millions of tons of plastic were produced around the world and it is expected an increase trend for the next years. Plastic production in Brazil was approximately 6 millions of tons in $2013^{1}$. However, the disposal of this material still is a challenge due to its stability/long period of degradation ${ }^{2}$. Recycling can reduce the plastic disposal in the environment. Nevertheless, only $22 \%$ of all post-consumer plastic discarded was recycled in Brazil ${ }^{1}$.

It is in this context, the use of environmentally degradable polymers (EDPs) is an alternative for reducing the degradation time of plastic materials ${ }^{3}$. Although EDPs have already been marketed, their applications are still limited due to the high cost and limited properties when compared to conventional polymers. The use of biodegradable-conventional polymer blends is one of the strategies to overcome these difficulties. Moreover, the use of organic fillers, such as vegetable fibers, in polymeric matrices is also an alternative to increase biodegradability as well as reduce the cost of the final product ${ }^{4-7}$. However, the adhesion between polymer-polymer and/or polymer-filler is often an issue that can impair in the final material properties.

Among the available EDPs, poly-caprolactone (PCL) has attracted interest in the substitution of conventional polymers because it is one of the few synthetic polymers that is biodegradable ${ }^{8}$. The biodegradability of PCL is due

*e-mail:mgabriela@unifal-mg.edu.br

Daiane C. Borghesi and Maíra F. Molina equally contributed to this work. to its chemical structure: a linear aliphatic polyester, which is hydrolysable at the ester linkage, allowing for chain scission. This allows for degradation by microorganism that utilize PCL as carbon/energy source, generating carbon dioxide and causing weight $\operatorname{loss}^{8}$. Moreover, processing ability of PCL by extrusion as well as its compatibility with other materials, make it an attractive polymer for several applications ${ }^{8,9}$. PCL-starch blends have been studied and the effects of starch on mechanical properties and biodegradation time were evaluated ${ }^{10-13}$. In addition, PCL-natural-organic fillers (eggshell, coconut, abaca, kenaf, seaweed, rice straw, sisal) composites have also been investigated ${ }^{2,14-20}$. The advantages of using natural-organic fillers include low cost, high abundance and low density ${ }^{2}$. Coffee husk $(\mathrm{CH})$ is a fibrous mucilaginous sub-product of coffee dry processing ${ }^{21}$ and represents about $50 \%$ of the coffee bean weight $^{22}$. Due to the presence of caffeine, tannins and other organic compounds, coffee husk is toxic for feeding, but has been used as fertilizer, stall bedding, flux in ceramic tiles, biomass and for water purification ${ }^{22-25}$. However, as world's annual coffee production is about 8.5 tons, only a small fraction of available coffee husk is used for these listed applications ${ }^{26}$. Thus, this material has great potential as natural-organic filler to be incorporate in polymer matrix due to its abundancy and low cost.

The aim of this study was to investigate the biodegradability of a new PCL-coffee husk composite film for potential application as EDP. Macroscopic, visual and thermal analyses were performed to evaluate coffee husk incorporation in PCL matrix. Moreover, biodegradation in soil was evaluated for 120 days by weight loss measurements, and particle size and microbiological analyses were carried out to characterize the soil. 


\section{Materials and methods}

\subsection{Preparation of the Films}

Poly-caprolactone $(\mathrm{Mn} \sim 80,000)$ was purchased from Sigma-Aldrich (USA). A local farmer (Andradas-MG/ Brazil) gently supplied coffee (Coffea arabica) husk. The composites were prepared by incorporation of coffee husk $(\mathrm{CH})$ into PCL matrix. Briefly, $\mathrm{CH}$ was previously dried in an oven at $105^{\circ} \mathrm{C}$ for 24 hours. Then, the dried husk was grinded and sieved in a $200 \mathrm{mesh}$ sieve. PCL by itself and with different concentrations ( 1.0 and $5.0 \% \mathrm{w} / \mathrm{w})$ of coffee husk was continuously extruded in a micro single screw extruder $\left(A X^{\circledR}\right)$ at $100{ }^{\circ} \mathrm{C}$. After extrusion, the extrudates were cold in a water bath at room temperature and cut in pellet shape. Pellet samples of $1 \mathrm{~g}$ of each formulation were heat pressed at $100{ }^{\circ} \mathrm{C}$ in order to prepare PCL, PCL1CH and PCL5CH films.

\subsection{Macroscopic Analysis}

Macroscopic analysis of composite films as prepared were carried out to evaluate color, filler dispersion (uniformity), opacity and flexibility. Flexibility was qualitatively measured by the ability of handling the film at different directions without compromising its physical integrity. In addition, after 120 days of biodegradation, flexibility and physical integrity of the films were also analyzed.

\subsection{Visual Analysis}

Visual analysis of PCL and PCL-CH composite films was carried out in a Stereoscope (Olympus) to evaluate the filler incorporation in the polymeric matrix. In addition, photographs of films were taken after each period of biodegradation.

\subsection{Thermal Analysis}

Differential Scanning Calorimetry (DSC) was performed on a DSC 2920 (TA Instruments) in order to identify the melting temperature $\left(\mathrm{T}_{\mathrm{m}}\right)$ and enthalpy of fusion $\left(\Delta \mathrm{H}_{\mathrm{m}}\right)$ of each sample analyzed (PCL, PCL1CH and PCL5CH films). Each film was previously dried in a desiccator for 24 hours and cut in small pieces to obtain about $200 \mathrm{mg}$ of sample. Then, the sample was heated in a platinum DSC pan from $30^{\circ} \mathrm{C}$ up to $120^{\circ} \mathrm{C}$, at heating rate $10^{\circ} \mathrm{C} \mathrm{min}^{-1}$, under nitrogen atmosphere. Average of duplicates was used to determine the melting temperature and the enthalpy of fusion of each film. Furthermore, the crystallinity degree $\left(\mathrm{X}_{\mathrm{c}}\right)$ was estimated by the following equation ${ }^{27}$ :

$$
X_{c}=\frac{\Delta H_{m}}{\Delta H_{m}^{0} \times W} \times 100
$$

$$
\begin{aligned}
& \text { Where: } \\
& X_{c}: \text { Crystallinity degree } \\
& \Delta H_{m}: \text { Experimental fusion enthalpy }\left(\mathrm{Jg}^{-1}\right) \\
& \Delta H_{m}^{0}: \text { Fusion enthalpy of } 100 \% \text { crystalline PCL } \\
& W: \text { Fraction of PCL in the sample }(\mathrm{w} / \mathrm{w})
\end{aligned}
$$

\subsection{Soil Characterization}

Particle size distribution and microbiological analyses of the soil were performed before it has been used for biodegradation study. Granulometric analysis was carried out according to NBR $6457(1986)^{28}$ and NBR $7181(1984)^{29}$. The percentage of humidity was calculated by the weight difference before $\left(\mathrm{m}_{1}\right)$ and after $\left(\mathrm{m}_{2}\right)$ drying the soil at $105^{\circ} \mathrm{C}$ for 24 hours, divided by the dried soil mass (Equation 2). Average of triplicates was used to determine the percentage of humidity.

$$
h=\frac{m_{1}-m_{2}}{m_{2}} \times 100
$$

Where:

$h$ : Percentage of humidity

$m_{1}$ : Mass of wet soil

$m_{2}$ : Mass of dried soil

\subsection{Microbiological Analyses}

Microbiological analyses of soil were performed according to Silva et al. (2010) methodology ${ }^{30}$. Briefly, the Total Viable Count (TVC) technique was used to count the microorganism population in the soil by the pour plate technique in sterile plate count agar (PCA). For mold and yeast counting, surface plate technique in Sabouraud broth with chloramphenicol was carried out. Results for each dilution were expressed in $\mathrm{CFU} / \mathrm{ml}$. Total coliforms, thermophili coliforms and $E$. coli numbers were counted by the most probable number (MPN) methodology using Lauryl tryptose (LSB) broth. Results were expressed in MPN/ml for each dilution.

\subsection{Biodegradation study}

For biodegradation study, films were cut in $1 \mathrm{~cm}^{2}$, washed with $70 \%$ ethanol and dried in a desiccator until constant weight for determination of the initial mass $\left(\mathrm{M}_{\mathrm{i}}\right)$. Then, 12 samples of each formulation were buried in the soil (city of Andradas/MG, Brazil) to a depth of 3 to $5 \mathrm{~cm}$. After 30 days, 3 samples of each formulation were taken from the soil, washed with $70 \%$ ethanol and placed in a desiccator until constant weight to determine the final mass $\left(\mathrm{M}_{\mathrm{f}}\right)$. This procedure was repeated every 30 days until 120 days of study. Average of triplicates was used to determine the percentage of weight loss, according to the following Equation 3:

Weight loss $=\frac{M_{i}-M_{f}}{M_{i}} \times 100$

Where:

$M_{i}:$ mass at day 0

$M_{f}$ mass at day $\mathrm{Y}$

$Y:$ is the period after biodegradation $(30,60,90$ and 120$)$ 
In order to determine the statistical significance of the difference in the weight loss, ANOVA and Tukey's honestly significant difference methods were used. For all experiments, $p<0.05$ was considered significant.

\section{Results and discussion}

\subsection{Macroscopic and Visual Analyses}

PCL-coffee husk composite films were prepared by incorporation of 1.0 and $5.0 \%(\mathrm{w} / \mathrm{w})$ of filler (samples PCL1CH and PCL5CH, respectively) in the polymeric matrix. Table 1 summarizes the macroscopic examination of PCL and PCL-CH composite films as prepared.

Table 1: Macroscopic examination of PCL film and PCL-coffee husk composite films.

\begin{tabular}{lcccc}
\hline Sample & Color & Uniformity & Opacity & Flexibility \\
\hline PCL & White & $\mathrm{XXX}$ & $\mathrm{X}$ & $\mathrm{XXX}$ \\
PCL1CH & Beige & $\mathrm{XX}$ & $\mathrm{XX}$ & $\mathrm{XXX}$ \\
PCL5CH & Brown & $\mathrm{X}$ & $\mathrm{XXX}$ & $\mathrm{XX}$ \\
\hline
\end{tabular}

$\mathrm{X}$ : low; XX: medium; XXX: high.

PCL forms flexible and uniform films. However, addition of filler can compromise its flexibility. After $1.0 \%$ of $\mathrm{CH}$ addition, no significant difference on flexibility was observed for PCL1CH composite film when compared to PCL film. Nevertheless, PCL5CH composite film was slightly less flexible than PCL and PCL1CH films. Visual analysis was carried out in a stereoscope to support macroscopic examination of samples. Figure 1 shows the photographs (25x magnification) of films as prepared. PCL is a crystalline polymer and forms white and opaque film by heated pressing. As expected, after $\mathrm{CH}$ addition, darker films were obtained due to the brown color of dried coffee husk. In addition, higher the percentage of coffee husk added to PCL matrix, darker was the color displayed by the composite film. It also can be observed better dispersion of filler in the matrix in the PCL1CH composite film when compared to PCL5CH. Coffee husk agglomeration was observed in PCL5CH composite film, compromising the uniformity of this sample.

\subsection{Thermal Analysis}

Melting temperature and fusion enthalpy are important parameters to estimate crystallinity degree of polymers. DSC results and crystallinity degree of composites are shown in Table 2. The fusion enthalpy of $100 \%$ crystalline PCL () used for calculation was $135 \mathrm{Jg}^{-1}$, as reported by Nagata and Yamamoto $(2009)^{31}$. PCL is a thermoplastic semi crystalline polymer and is soluble in many solvents. It has low melting temperature and crystallizes at room temperature ${ }^{32}$. Simon et al. (2007) reported that crystallization of PCL is only influenced by composite composition and crystallization temperature ${ }^{32}$.

According to Table 2, the incorporation of coffee husk in PCL matrix has not significantly changed the melting temperatures of the composites. Similar result was found by Neppalli et al. (2011) that found no differences in melting temperature between the PCL matrix and PCL-organoclay composites (1.0, 3.0 and $5.0 \% \mathrm{w} / \mathrm{w})$ prepared by casting technique ${ }^{33}$. Leite et al. (2010) have studied the incorporation of coconut fiber in PCL matrix and did not reported changes on melting temperature of $99 \%$ PCL-1\% coconut fiber composite ${ }^{16}$. Regarding to the enthalpy of fusion, in comparison to PCL, PCL1CH fusion enthalpy was slightly increased, while a considerably increased fusion enthalpy was found for PCL5CH. In respect to the degree of crystallinity, it was expected that $\mathrm{CH}$ incorporation in the PCL matrix would increase composites crystallinity, because filler particles can act as nucleation agents. However, only PCL5CH showed significant increase on the degree of crystallinity. This suggest that the aspect ratio of PCL-coffee husk plays an important role on the crystalline morphology of the polymer matrix. Miltner et al. (2010) reported that the crystalline/amorphous interface of PCL-nanoparticles composites was related to aspect ratio, dispersion quality, and polymer-filler contact surface provided ${ }^{34}$. In addition, Neppali et al. (2011) argued that the quantity and dispersion of this filler is key in tuning its nucleating effect, since the presence of dispersed filler can even slow down the crystal growth rate ${ }^{33}$. Therefore, as observed in the visual analysis (Figure 1), coffee husk was better dispersed in PCL1CH than in PCL5CH, what may also explain similar crystallinities found PCL and PCL1CH.

\subsection{Biodegradation study}

Crystallinity often controls the biodegradation rate of polymers, because biodegradation preferentially occurs in the amorphous domains of the polymeric matrix ${ }^{33}$. Biodegradation study of PCL-coffee husk composites was carried out in soil for 120 days. Figure 2 shows the photographs of PCL, PCL1CH and PCL5CH before and after each period of the biodegradation study. As expected, higher decomposition was associated to the increase of the coffee husk amount and time of biodegradation.

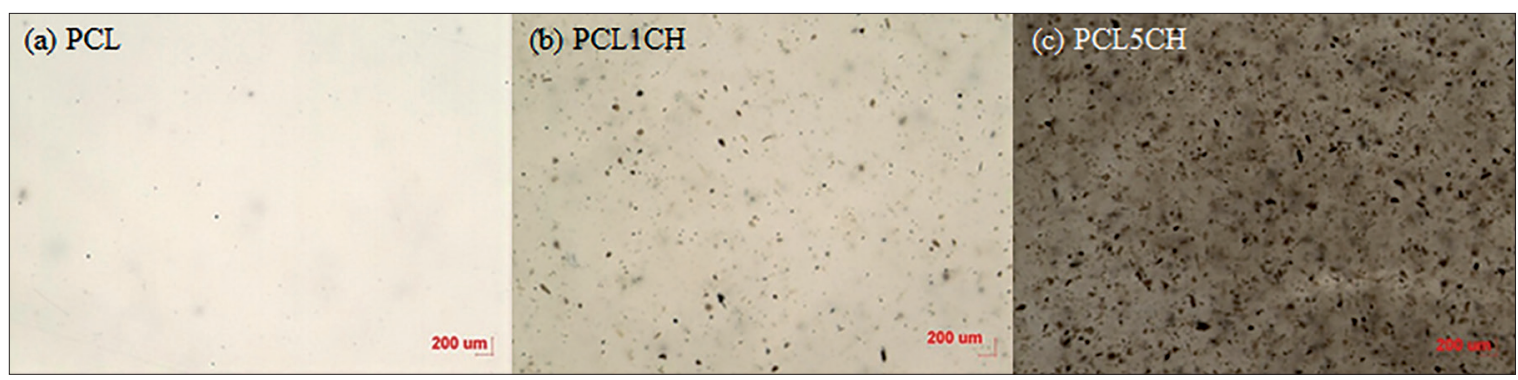

Figure 1: Photographs of films: (a) PCL, (b) PCL1CH and (c) PCL5CH. 
Table 2: Melting temperature, fusion enthalpy and crystallinity degree of PCL and PCL-coffee husk composite films.

\begin{tabular}{lccc}
\hline Sample & $\mathbf{T m}\left({ }^{\circ} \mathbf{C}\right)$ & $\boldsymbol{\Delta H}(\mathbf{J} / \mathbf{g})$ & $\mathbf{X c}(\mathbf{\%})$ \\
\hline PCL & 60.95 & 59.47 & 43.73 \\
PCL1CH & 60.81 & 60.76 & 45.13 \\
PCL5CH & 59.30 & 68.17 & 52.76 \\
\hline
\end{tabular}

In relation to the macroscopic analysis of samples after 120 days of biodegradation, the physical integrity of films were preserved, expect for the PCL5CH composite film that was cracked. Moreover, all films were more brittle (less flexible) after biodegradation. It indicates a reduction in the amorphous phase of PCL matrix and, consequently, an increase in the degree of crystallinity of the films. Leite et al. (2010) also reported an increase in the crystallinity degree of PCL and PCL-coconut fiber composites after 17 weeks of biodegradation ${ }^{16}$. Indeed, microorganisms preferably degrade amorphous domains of the polymeric matrix because of the easy access to these regions ${ }^{16}$. The presence of microorganisms can be observed in all films since 60 days of biodegradation (Figure 2). However, photographs at 120 days show higher amount of microorganisms on the surface of the composite films PCL1CH and PCL5CH in comparison to PCL. According to Lo Re et al. (2013), natural fibers can promote bacterial adhesion on composites and accelerate the

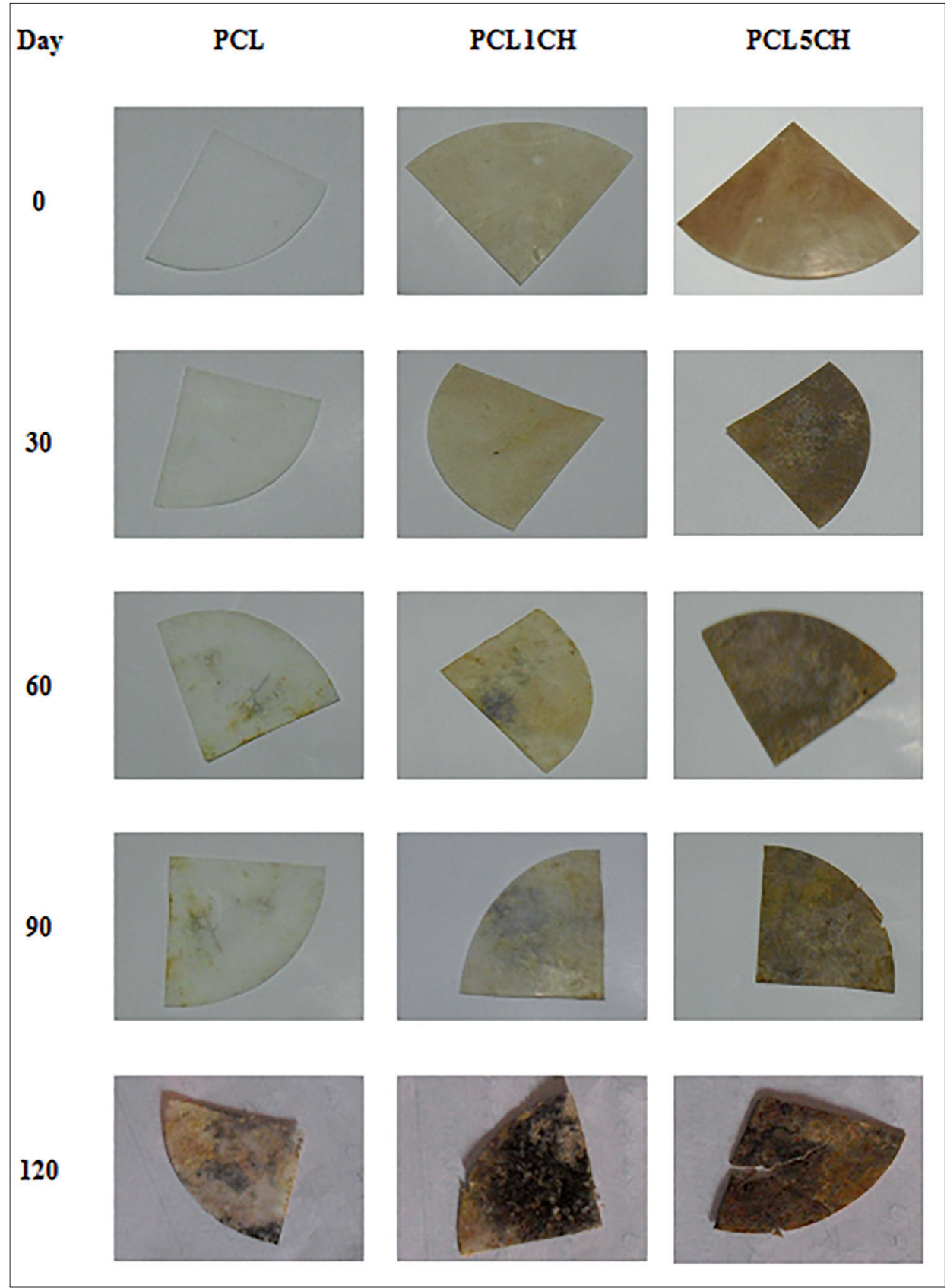

Figure 2: Photographs of PCL, PCL1CH and PCL5CH films during the biodegradation test. 
biodegradation rate $^{2}$. The authors also reported that higher surface roughness increases biodegradation by providing more sites for bacterial colonies settling and proliferation ${ }^{2}$. The biodegradation rate of films was evaluated by weight loss measurements. Table 3 summarizes the weight loss of films during the period of biodegradation. Weight loss measurements confirmed visual analysis results. After 30 days, PCL5CH composite film showed higher percentage of weight loss than PCL and PCL1CH films. It can be attributed to the higher amount of coffee husk in this film. However, from 60 to 120 days of biodegradation, the composites films PCL1CH and PCL5CH showed similar percentage of weight loss. This analogous biodegradation performance suggests that the presence of coffee husk can accelerate PCL biodegradation. Actually, the percentage of weight loss of the composites films PCL1CH and PCL5CH at these periods (60, 90 and 120 days) was about twice of PCL film. Moreover, except for 30 days of biodegradation, the percentage of weight loss of both composites films was higher than the percentage of coffee husk in the composite film. This indicates polymeric matrix (PCL) biodegradation in place of coffee husk, which serves as support for microorganisms' adhesion ${ }^{2}$.

Table 3: Percentage of weight loss of films during the period of biodegradation.

\begin{tabular}{lcccc}
\hline \multirow{2}{*}{ Sample } & \multicolumn{4}{c}{ Percentage of weight loss (\%) } \\
& $\mathbf{3 0}$ days & $\mathbf{6 0}$ days & $\mathbf{9 0}$ days & $\mathbf{1 2 0}$ days \\
\hline PCL & $1.56 \pm 0.25 \mathrm{~A}$ & $2.56 \pm 0.08 \mathrm{~A}$ & $4.53 \pm 1.76 \mathrm{~A}$ & $6.18 \pm 1.41 \mathrm{~A}$ \\
PCL1CH & $1.90 \pm 0.10 \mathrm{~A}$ & $4.96 \pm 0.73 \mathrm{~B}$ & $9.14 \pm 0.61 \mathrm{~B}$ & $13.96 \pm 2.16 \mathrm{~B}$ \\
PCL5CH & $3.25 \pm 0.54 \mathrm{~B}$ & $7.45 \pm 1.67 \mathrm{~B}$ & $11.60 \pm 1.21 \mathrm{~B}$ & $14.80 \pm 2.69 \mathrm{~B}$ \\
\hline
\end{tabular}

$\overline{\text { Different letters means significantly different results (Tukey test } p>0.05 \text { ). }}$.

\subsection{Soil Characterization}

Soil plays an important role for biodegradation. Temperature, humidity, chemical composition, $\mathrm{pH}$, geographical position and microbiological activity of soil are crucial parameters for polymer biodegradation ${ }^{35}$. Therefore, we characterized the soil used for biodegradation study according to the percentage of humidity, particle size distribution and microbiological counting. The soil percentage of humidity, calculated by Eq. 2, was $18.28 \%$. Soil percentage of humidity is affected by weather conditions (temperature and rainfall), irrigation and composition/particle size distribution, which determine the water-holding capacity of the soil ${ }^{35}$.

\subsection{Particle size distribution}

Particle size plays an important role for soil porosity, which directly affects the water amount that penetrates in the soil, the gas exchange rates and the heat transfer rates ${ }^{35}$. Granulometric structure of soil is shown in Figure 3. As it can be observed, size distribution of particles was $24 \%$ clay and silt, $65 \%$ sand (12\% fine, $28 \%$ medium and $25 \%$ coarse) and $11 \%$ gravel. Therefore, the soil was classified as sandy ${ }^{29}$. Gas exchange rate in sandy soils is high due to the porosity of this type of soil. Thus, aerobic microorganisms are expected to be found.

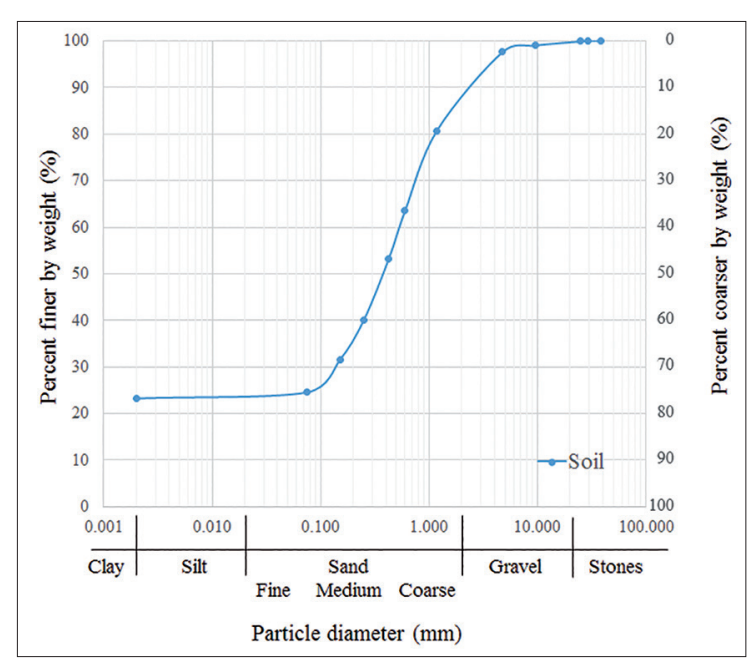

Figure 3: Granulometric structure of the soil.

\subsection{Microbiological analyses}

Bacteria, fungi and protozoa constitute microbial community of soil, but bacteria are found in higher numbers ${ }^{36}$. In comparison to molds, which are mostly aerobic microorganisms, bacteria have better chances of colonization, due to their capability of growing in both aerobic and anaerobic environments, at a wide range of temperature ${ }^{37}$. Bacteria and fungi can degrade biodegradable polymers. Therefore, we quantitatively estimated the bacterial and fungal populations in the soil used for biodegradation study of PCL and PCL-coffee husk composite films. Table 4 summarizes the TVC and MPN counting procedures results.

Table 4: Total Viable Count (TVC) and Most Probable Number (MPN) results.

\begin{tabular}{ll}
\hline Microorganisms & Counting \\
\hline Total microbial load & $5.4 \times 10^{5} \mathrm{CFU} / \mathrm{ml}$ \\
Molds and Yeasts & $1.6 \times 10^{4} \mathrm{CFU} / \mathrm{ml}$ \\
Total coliforms load & $>1.1 \times 10^{3} \mathrm{MPN} / \mathrm{ml}$ \\
Thermophile coliforms & $>1.1 \times 10^{3} \mathrm{MPN} / \mathrm{ml}$ \\
Escherichia coli & $>1.1 \times 10^{3} \mathrm{MPN} / \mathrm{ml}$ \\
\hline
\end{tabular}

As expected, bacteria and fungi were found in substantial amounts in the soil. However, the number of bacterial colony forming units was superior to fungal CFU. In addition, Escherichia coli was identified by MPN counting procedure. Mukherjee and Chatterjee (2014) showed E. coli (isolated from hydrocarbon effluent enriched soil) ability to degrade plastic bags in laboratory conditions ${ }^{38}$. Lo Re et al. (2013) studied the degradation of mater-bi ${ }^{\circledR} /$ kenaf fiber composites in compost and identified Staphylococci aggregates on the composite surface ${ }^{2}$. The authors attributed the presence of Staphylococci to the high extracellular lignocellulolytic activity of this bacteria type ${ }^{2}$. Although we have only identified $E$. coli bacterium, we suggest that several other bacterial types are present in the analyzed soil due to its composition, humidity and total microbial load. 


\section{Conclusions}

We successfully demonstrated the incorporation of coffee husk in the PCL matrix by preparing PCL-coffee husk composite films. The incorporation of coffee husk has multiples roles: (i) it works as organic filler in the polymeric matrix; (ii) it serves as support for microorganisms' adhesion; (iii) it increases the polymeric biodegradation rate; (iv) it reuses a sub-product of dry coffee processing; and (v) it reduces the final cost of the polymeric composite. Therefore, this composite has potential application as EDP material.

\section{Acknowledgments}

The authors thank Prof. Rosana Siqueira (Metrocamp Campinas/SP, Brazil) for the support of microbiological analyses.

\section{References}

1. Associação Brasileira de Industria do Plástico. Perfil 2014: Indústria brasileira de transformação de material plástico. [Internet]. [cited 2015 07-16-2015]. Available from: http://file.abiplast. org.br/download/links/2015/perfil_abiplast_2014_web.pdf.

2. Lo Re G, Morreale M, Scaffaro R, La Mantia FP. Biodegradation paths of Mater-Bi (R)/kenaf biodegradable composites. Journal of Applied Polymer Science. 2013;129(6): 3198-3208. http:// dx.doi.org/10.1002/app.39027

3. Innocentini-Mei LH, Mariani P. Visão geral sobre polimeros ou plásticos ambientalmente degradáveis PADs. Campinas: Editora Flamboyant; 2005.

4. Bledzki AK, Reihmane S, Gassan J. Properties and modification methods for vegetable fibers for natural fiber composites. Journal of Applied Polymer Science. 1996;59(8):1329-1336. http://dx.doi. org/10.1002/(SICI)1097-4628(19960222)59:8<1329::AIDAPP17>3.0.CO;2-0

5. Bismarck A, Mohanty AK, Aranberri-Askargorta I, Czapla S, Misra M, Hinrichsen G, et al. Surface characterization of natural fibers; surface properties and the water up-take behavior of modified sisal and coir fibers. Green Chemistry. 2001;3(2):100-107. http://dx.doi.org/10.1039/B100365H

6. Zini E, Baiardo M, Armelao L, Scandola M. Biodegradable polyesters reinforced with surface-modified vegetable fibers. Macromolecular Bioscience. 2004;4(3):286-295. http://dx.doi. org/10.1002/mabi.200300120

7. Bledzki AK, Gassan J. Composites reinforced with cellulose based fibres. Progress in Polymer Science. 1999;24(2):221-274. http://dx.doi.org/10.1016/S0079-6700(98)00018-5

8. Goldberg D. A review of the biodegradability and utility of poly(caprolactone). Journal of environmental polymer degradation. 1995;3(2):61-67. http://dx.doi.org/10.1007/BF02067481

9. Ray SS, Bousmina M. Biodegradable polymers and their layered silicate nano composites: In greening the 21 st century materials world. Progress in Materials Science. 2005;50(8):962-1079. http://dx.doi.org/10.1016/j.pmatsci.2005.05.002

10. Ghavimi AAS, Ebrahimzadeh MH, Solati-Hashjin M, Abu Osman NA. Polycaprolactone/starch composite: fabrication, structure, properties, and applications. Journal of biomedical materials research Part A. 2015;103(7):2482-2498. http:// dx.doi.org/10.1002/jbm.a.35371
11. Ghavimi SAA, Ebrahimzadeh MH, Shokrgozar MA, SolatiHashjin M, Abu Osman NA. Effect of starch content on the biodegradation of polycaprolactone/starch composite for fabricating in situ pore-forming scaffolds. Polymer Testing. 2015;43:94102. http://dx.doi.org/10.1016/j.polymertesting.2015.02.012

12. Ortega-Toro R, Morey I, Talens P, Chiralt A. Active bilayer films of thermoplastic starch and polycaprolactone obtained by compression molding. Carbohydrate Polymers. 2015;127:282290. http://dx.doi.org/10.1016/j.carbpol.2015.03.080

13. Mariani PDSC, Vinagre Neto AP, Silva Junior JP, Cardoso EJBN, Esposito E, Innocentini-Mei LH. Mineralization of poly(epsilon-caprolactone)/adipate modified starch blend in agricultural soil. Journal of Polymers and the Environment. 2007;15(1):19-24. http://dx.doi.org/10.1007/s10924-006-0044-1

14. Barghini A, Ivanova VI, Imam SH, Chiellini E. Poly-(epsilonCaprolactone) (PCL) and Poly(Hydroxy-Butyrate) (PHB) Blends Containing Seaweed Fibers: morphology and ThermalMechanical Properties. Journal of Polymer Science Part a-Polymer Chemistry. 2010;48(23): 5282-5288. http://dx.doi. org/10.1002/pola.24327

15. Cocca M, Avolio R, Gentile G, Di Pace E, Errico ME, Avella $\mathrm{M}$. Amorphized cellulose as filler in biocomposites based on poly(epsilon-caprolactone). Carbohydrate Polymers. 2015;118:170182. http://dx.doi.org/10.1016/j.carbpol.2014.11.024

16. Leite MCAM, Furtado CRG, Couto LO, Oliveira FLBO, Correia TR. Evaluation of Biodegradation Poly(epsilonCaprolactone)/Green Coconut Fiber. Polimeros Ciencia e Tecnologia. 2010;20(5):339-344. http://dx.doi.org/10.1590/ S0104-14282010005000063

17. Teramoto N, Urata K, Ozawa K, Shibata M. Biodegradation of aliphatic polyester composites reinforced by abaca fiber. Polymer Degradation and Stability. 2004;86(3):401-409. http://dx.doi. org/10.1016/j.polymdegradstab.2004.04.026

18. Wu CS, Liao HT. Polycaprolactone-Based Green Renewable Ecocomposites Made from Rice Straw Fiber: characterization and Assessment of Mechanical and Thermal Properties. Industrial \& Engineering Chemistry Research. 2012;51(8):3329-3337. http://dx.doi.org/10.1021/ie202002p

19. Petit MG, Correa Z, Sabino MA. Degradation of a Polycaprolactone/ Eggshell Biocomposite in a Bioreactor. Journal of Polymers and the Environment. 2015;23(1):11-20. http://dx.doi.org/10.1007/ s10924-014-0655-x

20. di Franco CR, Cyras VP, Busalmen JP, Ruseckaite RA, Vazquez A. Degradation of polycaprolactone/starch blends and composites with sisal fibre. Polymer Degradation and Stability. 2004;86(1):95-103. http://dx.doi.org/10.1016/j. polymdegradstab.2004.02.009

21. Pandey A, Soccol CR, Nigam P, Brand D, Mohan R, Roussos S. Biotechnological potential of coffee pulp and coffee husk for bioprocesses. Biochemical Engineering Journal. 2000;6(2):153162. http://dx.doi.org/10.1016/S1369-703X(00)00084-X

22. Gonçalves M, Guerreiro MC, Oliveira LCA, Solar C, Nazarro M, Sapag K. Micro Mesoporous Activated Carbon from Coffee Husk as Biomass Waste for Environmental Applications. Waste and Biomass Valorization. 2013;4(2):395-400. http://dx.doi. org/10.1007/s12649-012-9163-1

23. Acchar W, Dultra EJV, Segadaes AM. Untreated coffee husk ashes used as flux in ceramic tiles. Applied Clay Science. 2013;7576:141-14. http://dx.doi.org/10.1016/j.clay.2013.03.009 7.

24. Getachew T, Hussen A, Rao VM. Defluoridation of water by activated carbon prepared from banana (Musa paradisiaca) peel and coffee (Coffea arabica) husk. International Journal of Environmental Science and Technology. 2015;12(6):1857-1866. http://dx.doi.org/10.1007/s13762-014-0545-8 
25.Gonçalves M, Guerreiro MC, Oliveira LCA, de Castro CS. A friendly environmental material: iron oxide dispersed over activated carbon from coffee husk for organic pollutants removal. Journal of Environmental Management. 2013;127:206-211. http://dx.doi.org/10.1016/j.jenvman.2013.05.017

26. Associação Brasileira da Indústria de Café. Produção Mundial de Café - Principais Países Produtores 2014. Rio de Janeiro: ABIC; 2014. [cited 2015 Jul 16]. Available from: http://www. abic.com.br/publique/cgi/cgilua.exe/sys/start.htm?sid=61.

27. Turi EA, editor. Thermal characterization of polymeric materials. 2nd ed. New York: Academic Press; 1981.

28. Associação Brasileira de Normas Técnicas - ABNT. NBR 6457: Amostras de solo - Preparação para ensaios de compactação e ensaios de caracterização. São Paulo: ABNT; 1986.

29. Associação Brasileira de Normas Técnicas - ABNT. NBR 7181: Solo - Análise granulométrica. São Paulo: ABNT;1984.

30. Silva N, Junqueira VCA, Silveira NFA, Taniwaki MH, Santos RFS, Gomes RAR. Manual de Métodos de Análise Microbiológica de Alimentos e Água. 4a ed. São Paulo: Livraria Varela; 2010.

31. Nagata M, Yamamoto Y. Synthesis and characterization of photocrosslinked poly( $\varepsilon$-caprolactone)s showing shape-memory properties. Journal of Polymer Science Part A Polymer Chemistry. 2009;47(9):2422-2433. http://dx.doi.org/10.1002/pola.23333

32. Simon D, Holland A, Shanks R. Poly(caprolactone) thin film preparation, morphology, and surface texture. Journal of Applied Polymer Science. 2007;103(2):1287-1294. http:// dx.doi.org/10.1002/app.25228
33. Neppalli R, Causin V, Marega C, Saini R, Mba M, Marigo A. Structure, Morphology, and Biodegradability of Poly(epsiloncaprolactone)-Based Nanocomposites. Polymer Engineering and Science. 2011;51(8):1489-1496. http://dx.doi.org/10.1002/ pen. 21948

34. Miltner HE, Watzeels N, Goffin AL, Duquesne E, Benali S, Dubois P, et al. Quantifying the degree of nanofiller dispersion by advanced thermal analysis: application to polyester nanocomposites prepared by various elaboration methods. Journal of Materials Chemistry. 2010;20(42):9531-9542. http:/ dx.doi.org/10.1039/C0JM01673J

35. Bastioli C. Handbook of Biodegradable Polymers. Shrewsbury: Rapra Technology; 2005.

36. Gennaro LA. Estrutura, micromorfologia e microbiologia do solo em dois sistemas de manejo. [Dissertation]. Campinas: Universidade Estadual de Campinas; 2011.

37. Cordi L. Estudo da biodegradação dos filmes de poli (e-caprolactona), da blenda poli (e-caprolactona)/amido e do composito poli (e-caprolactona)/amido/po de fibra de coco por fungos e bacterias. [Dissertation] Campinas: Universidade Estadual de Campinas; 2008.

38. Suman M, Shamba C. A comparative study of commercially available plastic carry bag biodegradation by microorganisms isolated from hydrocarbon effluent enriched soil. International Journal of Current Microbiology and Applied Sciences. 2014;3(5):318-325. 